\title{
Anyanyelv és nemzetiség mint az interetnikus kapcsolatok mutatója Erdély magyar lakosságának példáján
}

\author{
Mother tongue and ethnicity as statistical \\ indicators of interethnic relations: the case of \\ Hungarians in Transylvania
}

\author{
TÁTRAI PATRIK
}

KULCSSZAVAK: asszimiláció, szórvány, etnikai identitás, Románia

ABSZTRAKT: Térségünk országainak népszámlálásaiban általában megjelenik kéł kategória (anyanyelv, nemzetiség), amelyek alapján a népesség etnikai összetételét vizsgálhatjuk. Jelen tanulmányban arra keresem a választ, hogy milyen kapcsolatban áll egymással e két „statisztikai” kategória, milyen összefüggéseket lehet ebből kiolvasni, és hogy mindennek milyen térszerkezeti konzekvenciái vannak. Az anyanyelv és a nemzetiség eltérése fontos információk hordozója: a különbség nagyságából és változásának irányából nyelv- és nemzetváltási folyamatokra következtethetünk. Célom ezen folyamatok bemutatása Erdély magyar lakosságának körében négy népszámlálási időpontban (1930, 1966, 1992, 2002), nemzetiségi és területi bontásban.

Az anyanyelvi és nemzetiségi önbevallások eltérésének legfőbb okozói a különböző asszimilációs és disszimilációs folyamatok. A két kategória különbségének nagysága és iránya térben és idő́ben változó, leginkább az adott etnikum számával és területi elhelyezkedésével hozható összefüggésbe, de a hatalmi viszonyok is jelentős szerepet játszanak benne. Erdély magyar népességét tekintve a térbeli elhelyezkedés túnik a legfontosabb tényezőnek: a magyar nemzetiségi többletú területeket általában a szórványidentitás jellemzi, míg a magyar anyanyelvi többletú részeken a kiegyensúlyozott magyar etnikai identitás dominál.

KEYWORDS: assimilation, diaspora, ethnic identity, Romania

ABSTRACT: In most East Central European countries census data regarding ethnic affiliation are collected by two categories: mother tongue and ethnicity. As the census does not offer the possibility to declare multiple mother tongues or ethnicities, uncertain or multiple ethnic identities remain easily hidden in these databases.

The main aim of the present study is to outline the relation and the correspondence between these two "statistical" categories and to reveal the spatial consequences of these differences. The study also tries to shed some light on the assimilation and dissimilation processes of the Hungarian population in the last hundred years.

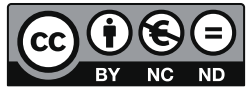


The Romanian census data of 1930, 1966, 1992 and 2002 reveal that the extent and direction of deviation between the values of mother tongue and ethnicity show regional and temporal changes. Generally speaking, this phenomenon is caused by assimilation; its direction and extent is determined by the size and spatial concentration of the ethnic groups and by the actual national and local power structures. Both ethnically mixed marriages and the socialisation in the majority language (e.g. in schools) can be identified as factors fostering assimilation. In the case of the Hungarian population of Transylvania the spatial position seems to be the most important factor: Communities with well-balanced Hungarian ethnic identity can be found in those territories where more people indicated Hungarian mother tongue rather than Hungarian ethnicity, while areas with inverse values are characterised by a 'diaspora' identity.

\section{Bevezetés}

A népszámlálások etnikai vonatkozású adatait vizsgálva Magyarországon és a környező országokban napjainkra már rendre megtalálható (legalább) két kategória, amely gyakran alapját képezi az etnikai kutatásoknak: a nemzetiség és az anyanyelv. Legtöbbször a népszámlálások nemzetiségi adatsoraival találkozunk, ezeket előszeretettel használják kutatók, politikusok egyaránt, és az egyes statisztikai hivatalok általában ezeket az adatokat publikálják a legrészletesebben az etnikai ismérvek közül. Azt, hogy milyen aktuális társadalmi-politikai, illetve népszámlálás-technikai háttere van az egyes kategóriáknak, és hogy ezek hogyan változtak a 19. század vége óta, már sokat elemezték (például Varga 1998a, Gyurgyík 2006a). Jelen tanulmányban a választ arra keresem, hogy milyen kapcsolatban áll egymással e két „statisztikai” kategória, milyen összefüggéseket lehet ebből kiolvasni, és hogy mindennek milyen térszerkezeti konzekvenciái vannak.

Az induláshoz először is értelmezni kell, mit jelent a Kárpát-medencében az, hogy valaki magyarnak vagy egyéb anyanyelvünek és/vagy nemzetiségünek vallja magát. A nemzetiségi bevallás térségünk legtöbb országában nem pusztán etnikai síkon értelmezhetö, azaz adott nemzetiség bevallása mást (többet) is jelenthet, mint hogy valaki valamelyik etnikumhoz sorolja magát. A népszámlálások alkalmával ugyanis a nemzetiségi bevallás - az aktuális társadalmi-politikai hangulattól, interetnikus viszonyoktól stb. függően - lehet a többség részéről „elvárt hüségnyilatkozat” az állam iránt, amely a kisebbségek körében azt eredményezheti, hogy egyes tagjaik, csoportjaik saját vélt vagy valós érdekeiket szem előtt tartva a többségi nemzetiséghez sorolják magukat. Ugyanez figyelhető meg a bizonytalan/többes etnikai kötődéssel rendelkezők körében, akik a népszámlálások idején rendszeresen az államalkotó nemzetiséghez iratkoznak. Az anyanyelvi bevallás már kevésbé „érzékeny” politikailag, mivel a nagy többség számára ez adottság, ${ }^{1}$ egy adott kultúra része, illetve az anyanyelvi eredmények már említett kisebb nyilvánossága is szerepet játszhat. 
Az anyanyelv és nemzetiség közötti különbség más síkon is értelmezhető. Európa keleti felében, így térségünkben is, az egyes nemzetek, nemzetiségek kultúrnemzeti alapon határozzák meg magukat, azaz az összetartozás alapja a közös nyelv, kultúra, valamint a közös származás mítosza vagy valósága, és ezek alapján a közös identitás (Romsics 2004, 9.). Ebben a felfogásban az (anya)nyelv szerepe meghatározó az etnikai identitásban. Ugyanakkor napjainkban térségünk legtöbb országa (Magyarország is!) egyszerre szerveződik kultúrnemzeti és államnemzeti alapon. ${ }^{2}$ Ez azt jelenti, hogy saját kisebbségei felé egyfajta államnemzet-koncepciót képvisel, míg az ország határain kívüli nemzetrészek felé kultúrnemzet-koncepciót. Ez a különbség (kultúrnemzeti identitás $\leftrightarrow$ az állam nemzetépítő tevékenysége) a kisebbségi helyzetben élők körében akár konfliktust is okozhat (Veres 2008, 45-48.), amit például az eltérő anyanyelvi és nemzetiségi bevallás is jelezhet.

\section{Az anyanyelvi és nemzetiségi kategória viszonya a szakirodalom tükrében}

A Kárpát-medencei magyar kisebbségeket a rendszerváltás időszakáig szinte egységesen anyanyelvi többlet jellemezte, természetesen jelentős regionális különbségekkel. A többi kisebbség esetében már más a helyzet. A magyarokon kívüli két - térségünkben általánosan elterjedt - kisebbség (német és cigány) esetében jól megfigyelhető, hogy milyen befolyással van földrajzi helyzete, lélekszáma (a cigányok többségének nyelvvesztése és gyenge etnikai öntudata is) az anyanyelvi és nemzetiségi bevallás kapcsolatára. Anyanyelv és nemzetiség kapcsolatára általánosan alkalmazott mutató az anyanyelv/nemzetiség×100 számítás alapján megkapott hányados (a továbbiakban: ANH). Értéke 100 alatt nemzetiségi, felette anyanyelvi többletet jelent. Az adatok alapján (1. táblázat) két országcsoport különíthető el. Az egyik csoportban gyakorlatilag minden kisebbség körében jelentős anyanyelvi többlet figyelhető meg (Szlovákia, Szlovénia), míg a többi országban az adott kisebbség lélekszámától és területi elhelyezkedésétől függ az ANH-mutató.

A táblázat alapján a következő kérdésekre keresem a választ: hogyan értelmezhetjük az anyanyelv-nemzetiség-különbséget, annak nagyságát, irányát? Mi áll eme különbség hátterében, mi okozhatja ezt? Kik alkotják az eltérő bevallású (hibrid) népességet? Mindezekre a választ Erdély ${ }^{3}$ magyar lakosságának népszámlálási önbevallása alapján próbálom megadni.

$\mathrm{Az}$ anyanyelv-nemzetiség-viszony értelmezésére történtek már kísérletek, azonban ezek egyike sem ad részletes, mindenre kiterjedő válaszokat. A szlovákiai nemzetiségek körében Gyurgyík László kísérelt meg e két kategória különbsége alapján következtetéseket levonni. A nemzetiségi többséggel jellemezhető etnikai csoportokat asszimiláló, az anyanyelvi többséggel rendel- 
1. táblázat: Az ANH-mutató a szomszédos országok három kisebbsége körében

\begin{tabular}{lrrrrrr}
\hline \multirow{1}{*}{ Ország/régió } & \multicolumn{2}{c}{ Magyar } & \multicolumn{2}{c}{ Német } & \multicolumn{2}{c}{ Cigány } \\
\cline { 2 - 7 } & 1991 & 2001 & 1991 & 2001 & 1991 & 2001 \\
\hline Szlovákia & 107,2 & 110,1 & 142,9 & 117,4 & 101,9 & 110,6 \\
Kárpátalja & 107,1 & 104,8 & 74,1 & 50,5 & 20,5 & 19,9 \\
Erdély & 101,0 & 101,0 & 83,8 & 76,6 & 41,8 & 44,7 \\
Vajdaság & 101,5 & 97,9 & 76,3 &.. & 85,2 & 75,5 \\
Pannon-Horvátország & 89,0 & 75,3 &.. & 84,7 & 118,5 & 84,6 \\
Muravidék & 107,0 & 120,6 & 229,0 & 450,0 & 150,2 & 124,3 \\
\hline
\end{tabular}

Megjegyzés: .. = nincs adat. Forrás: Kocsis 2003, 716-723.

kezőket pedig asszimilálódó közösségeknek tekinti (Gyurgyík 2006b., 78.). Ez a feltételezés egyrészt csak a szlovákiai viszonyokra lehet igaz (ld. a későbbiekben az erdélyi magyarság regionális különbségeit e tekintetben), másrészt túlzásnak érzem Szlovákiában a romák tömeges asszimilációjáról beszélni, illetve a magyarok esetében is kicsit általánosító a megfogalmazás. Azzal azonban egyetértek, hogy a „nemzeti hovatartozás kategóriája sokkal erősebb politikai konnotáció hordozója, mint az anyanyelv" (Gyurgyík 2006a., 20.). Gyurgyík szerint a nemzeti-etnikai közösségekhez tartozók hierarchikus rendbe sorolhatók az adott csoporthoz való tartozásuk erőssége szerint: magcsoport (azonos anyanyelv és nemzetiség), belső szféra (csak nemzetiség szerint tartozik a csoporthoz), külső szféra (csak anyanyelv) szerint tartozik a csoporthoz. Arról azonban csak részlegesen értekezik, hogy milyen törvényszerüségek húzódnak meg annak hátterében, hogy egyes személyek, csoportok eltérő anyanyelvet és nemzetiséget vallanak be a népszámlálások alkalmával (Gyurgyík 2006b. 81-82.). ${ }^{4}$

Mirnics Károly a vajdasági nemzetiségek (elsősorban a magyarok) példáján mutatja be a nemzeti hovatartozás és az anyanyelv statisztikai távolodását (Mirnics 1998, 56-58.). Megállapítása szerint a fenti jelenség (alterofónia) az asszimiláció következménye és egyben indikátora is, hiszen „a teljes asszimiláció folyamata a nyelvi asszimilációval kezdődik, és a nemzetiség elvesztésével zárul" (Mirnics 1998, 57.). Bár kijelentésével alapvetően egyetértek, magyarázata elsősorban a magyar nemzetiségü, de egyéb (főleg szerb) anyanyelvü lakosságra lehet csak igaz. Az említett két szerző véleménye között így máris találunk némi ellentmondást (Gyurgyík: anyanyelvi többlet $\rightarrow$ asszimiláció; Mirnics: nemzetiségi többlet $\rightarrow$ asszimiláció), ami világosan jelzi a probléma összetett voltát, valamint az országos/regionális különbségeket.

Az erdélyi magyarság fogyását, az asszimilációt vizsgálta Szilágyi N. Sándor is. Tanulmányában megállapítja, hogy „a nem magyar anyanyelvü magyarok jelenlétét inkább a nyelvi, és csak elhanyagolható mértékben az etnikai asszimilációval hozzuk összefüggésbe" (Szilágyi 2004, 165.). ${ }^{5}$ Mirnicshez ha- 
sonlóan a sorrendiséget tekintve úgy véli, hogy először következik be a nyelvi, és csak később az etnikai hasonulás. Szilágyi részletes, kidolgozott megállapításaival alapvetően egyetértek, bár azok elsősorban magyar-román viszonylatban, ott is a románság irányába mutató asszimiláció kapcsán állják meg helyüket. A magyar anyanyelvü, román nemzetiségü népesség kialakulásának hátterére nem tér ki. Gyurgyíkhoz hasonlóan részletezi viszont, hogy kik tartoznak a román anyanyelvü magyar nemzetiségüek körébe: az egyéni vagy közösségi nyelvcserén átesett magyarok (Szilágyi 2004, 165-166.).

Sebők László a szlavóniai magyar szórványok vizsgálatánál használja az anyanyelvi és nemzetiségi kritérium összehasonlítását. A kérdéskörrel összefüggésben nála találkozunk a szórványosodás szó használatával. A szlavóniai magyarok körében tapasztalható jelentős nemzetiségi többletet Szilágyi és Mirnics véleményéhez hasonlóan a nyelvi asszimilációval magyarázza (Sebők 2006, 189-190.).

Az erdélyi magyar anyanyelv-nemzetiség-viszonyt vizsgálva Horváth István - amellett, hogy az okokról nem szól - az eltérő etnikai azonosulású (nála hibrid) magyar népességet interetnikus kapcsolatai, illetve területegységek szerint is bemutatja. Az utóbbira vonatkozik fontos megállapítása is, hogy „a magyar anyanyelvű, de a magyartól eltérő etnikai identitású népesség területileg messzemenően koncentráltabb, mint a nyelvileg divergens magyar etnikumú népesség" (Horváth 2008, 10-12.).

Varga E. Árpád az erdélyi magyarság asszimilációs mérlegének felállításakor próbált következtetéseket levonni a két népszámlálási kategória különbségéből. Varga etnikumok szerint is bemutatja az anyanyelv-nemzetiség-viszony alakulását. Ráadásul nemcsak az asszimilációt, hanem asszimiláció és disszimiláció kombinációját is ott sejti egyes folyamatok hátterében. Magyar-román viszonylatban azonban mind a magyar anyanyelvi, mind a nemzetiségi többletet az asszimiláció számlájára írja. ${ }^{6}$ Sebőkhöz hasonlóan Varga is határozottan szórványjelenségnek tekinti a nemzetiségi többletet, ráadásul a kérdés időbeli dinamikájára is utal (Varga 2002, 198-199., 204.).

A szakirodalom alapján jól látszik az a viszonylagos bizonytalanság, ami a kérdést Kárpát-medencei összmagyar szinten jellemzi. Regionálisan kapunk ugyan lényegében kielégítő magyarázatokat (közülük Varga E. Árpád tanulmánya szolgál a legkomplexebb válasszal), de több részlet így is homályban marad. A fenti kutatások alapján az anyanyelv-nemzetiség-eltéréssel több fogalom is kapcsolatba hozható, amelyek elválaszthatatlanul hozzátartoznak a kérdéskör tanulmányozásához, az okok feltárásához; ezek az asszimiláció/disszimiláció, az identitás és a szórvány/szórványosodás. 


\section{Erdély magyar népessége az anyanyelvi és nemzetiségi statisztika alapján}

\section{0 elótt}

Települési szinten az anyanyelv-nemzetiség-viszonyt Erdélyben négy népszámlálás alapján vizsgálhatjuk, ezek pedig az 1930-as, 1966-os, 1992-es és 2002-es román népszámlálások. Részletes adatok állnak rendelkezésre az 1941-es magyar népszámlálásból is, de csak a terület északi részére. Vizsgálataimat a fenti négy időpontra alapozom, ami azért is különösen előnyös, mert így az államhatalom-váltásoknak az etnikai identitásra (vagy csak a statisztikai önbevallásra) gyakorolt hatása nem befolyásolja az összehasonlíthatóságot.

Az 1930. évi népszámlálást megelőző korszakban a népesség interetnikus kapcsolataira az anyanyelvet és a felekezetet összevető kereszttáblákból, illetve a népesség nyelvismeretét részletező adatokból következtethetünk. Mivel egy közösség életében a vallás jóval stabilabb jellemzon, mint az anyanyelv (ld. a moldvai csángókat), így feltételezhető, hogy az adott etnikumra jellemző felekezetektől eltérő kapcsolat valamilyen kettős identitást vagy a múltban lejátszódott asszimilációt jelent. Ez a jelenség ha a domináns népcsoport irányába mutat ${ }^{7}$ - akár sokkal tovább fennmaradhat, mint az eltérő anyanyelv és nemzetiség (Szilágyi 2004, 166-168.). A felekezettel szemben a nyelvismeret mint etnikai ismérv - a társadalmi és oktatási fejlődés ${ }^{8}$ következtében - csak a 20. század közepéig alkalmazható hitelesen.

A Trianont megelőző időszakról általánosan az mondható el, hogy az Erdélyre eső vármegyék területén a nem magyar jellegű felekezeteken belül jobban nőtt a magyarok száma és aránya, mint a „kizárólagos” magyar egyházakon belül. Ennek hátterében minden bizonnyal egyes kisebbségi csoportok valós vagy statisztikai nyelvváltása áll. A nyelvismereti adatok is hasonló információkat szolgáltatnak: 1910-ben a csak magyarul beszélők legnagyobb arányban a református és az unitárius egyházban találhatók; ezzel szemben a magyar anyanyelvű ortodoxok 41,6\%-a beszélt románul, az izraeliták 52,1\%-a pedig németül/jiddisül. A folyamatokat általánosítva az elmagyarosodás címkével illethetjük; azonban a választ arra, hogy e nyelvváltás/nemzetváltás mennyire volt tartós, csak az 1920 utáni időszak adta meg. 


\section{$1920-1966$}

Az 1930. évi népszámlálás időpontjától kezdve az anyanyelvi és nemzetiségi ismérv összehasonlításával a magát magyarnak valló népesség több jellemzőjét is tanulmányoztam. Vizsgáltam egyrészt a magyarok homogenitását - ami egyben választ ad a többes kötődésűek népszámlálás szerinti minimális számára is -, másrészt a többes kötődésűek etnikai összetételét, kötődésének irányát. Végül pedig megvizsgáltam mindezek területi vonatkozásait.

A 2. táblázatból kitűnik, hogy 1930-tól napjainkig folyamatosan csökken a magyar anyanyelvüek magyar nemzetiségüekhez viszonyított aránya, tehát az ANH-mutató. Ez azonban nem fejezi ki pontosan a két kategória különbségének nagyságát, erre alkalmasabb a homogenitási index. Két mutatóval operálhatunk tehát: a homogenitási index e kapcsolat nagyságát tükrözi, míg az ANH - bár informál az eltérés hozzávetőleges mértékéről, mégis - elsősorban a különbség irányát mutatja meg. Összességében a 2. táblázatból az derül ki, hogy egy 1966 óta viszonylag stabil homogenitási index mellett (tehát a magyarok maximális számából a magát mindkét ismérv szerint magyarnak vallók aránya 95\% körül mozog) egyre csökken az ANH értéke, ami az interetnikus kapcsolatok átrendeződését jelenti a magyar nemzetiségi többlet irányába.

Az ANH kezdeti kiemelkedően magas értéke több okra vezethető vissza. A legfőbb ezek közül a megváltozott statisztikai számbavétel, amely immár külön nemzetiségként regisztrálta a zsidókat és a cigányokat. Fontos kiemelni, hogy a korszak nagy anyanyelvi többlete elsősorban a magyar uralom alatt bekövetkezett, a magyarok irányába mutató asszimiláció eredménye. Ahol az asszimiláció teljesen befejeződött, ott az eltérő eredetű népesség magyarnak vallotta magát mindkét ismérv szerint, ellenben ahol még nem volt teljes a hasonulás, ott a származásuk szerinti nemzetiséget vallották be az emberek.

Az 1930-as népszámlálás anyanyelvi-nemzetiségi kereszttábláit nem publikálták. A települési szintű adatokból azonban levonható pár következtetés a magyar népesség interetnikus kapcsolatairól. Becslésem szerint az akkor magyar kötődésűek 9\%-át kitevő többes identitású népesség túlnyomó többsé-

2. táblázat: A magyar népesség interetnikus kapcsolatai Romániában, 1930-2002

\begin{tabular}{ccccccc}
\hline Év & $\begin{array}{c}\text { Magyar } \\
\text { anya- } \\
\text { nyelvú, fö }\end{array}$ & $\begin{array}{c}\text { Magyar } \\
\text { nemzeti- } \\
\text { ségü, fö }\end{array}$ & $\begin{array}{c}\text { Anyanyelve } \\
\text { és nemzeti- } \\
\text { sége egye- } \\
\text { zik, fö }\end{array}$ & $\begin{array}{c}\text { Legalább } \\
\text { egy kate- } \\
\text { gória szerint } \\
\text { magyar, fö }\end{array}$ & $\begin{array}{c}\text { Homogeni- } \\
\text { tási index }\end{array}$ & ANH \\
\hline 1930 & 1552563 & 1423459 &.. &.. & $91,0^{*}$ & 109,1 \\
1956 & 1653700 & 1587675 & 1564959 & 1676416 & 93,4 & 104,2 \\
1966 & 1651873 & 1619592 & 1602259 & 1669206 & 96,0 & 102,0 \\
1992 & 1639135 & 1624959 & 1590290 & 1673804 & 95,0 & 100,9 \\
2002 & 1443970 & 1431807 & 1397906 & 1477871 & 94,6 & 100,8 \\
\hline
\end{tabular}

Homogenitási index: az előző két oszlop hányadosa; * = saját becslés; .. = nincs adat. Forrás: Varga (1998b, 252., 255.) 
ge zsidó volt (47\%). A mindössze tíz évre visszanyúló magyar kisebbségi lét miatt nem feltételezek a korábbiaknál sokkal jelentősebb asszimilációt a románok irányába, mindössze a korábban elmagyarosodott szatmár-bihari és székelyföldi csoportjaik körében nőtt meg jelentősen az ANH értéke. Így - feltételezésem szerint - csupán az eltérő magyar bevallások 27\%-a kapcsolódott a románsághoz. Kiemelkedő még a németek (11\%) és a cigányok (10\%) részesedése.

1930-ban Erdély túlnyomó részén több magyar anyanyelvű lakos élt, mint magyar nemzetiségű. Magyar nemzetiségi többlet mindössze BeszterceNaszód megyét, a Mócföldet, valamint Szeben és Krassó-Szörény megyék ${ }^{9}$ hegyvidéki területeit jellemezte, tehát azokat a területeket, ahol a legkevesebb magyar élt (1. ábra). Az ANH-mutató legnagyobb értékeit Szatmárban rögzítették, ahol a magyar anyanyelvű cigányok, svábok és görög katolikusok (románok és ruszinok egyaránt) okozták az eltérést. Szintúgy jelentős különbség látható a Székelyföld egyes részein (pl. az Erdővidéken), ahol a korábban elmagyarosodott lakosság visszatért román nemzetiségéhez (vö. Oláh 1996). Feltünő még, hogy Bihar megye viszonylag kis magyar lakossággal rendelkező hegyvidéki területei is kiemelkedő értékekkel rendelkeznek; itt elsősorban a falusi zsidó és cigány lakosság vallotta magát magyar anyanyelvűnek.

Az interetnikus kapcsolatok területi jellemzői nemzetiségenként is vizsgálhatók. A román-magyar kapcsolatok legfőbb színtere a már említett szat-

1. ábra: Magyar anyanyelvűek és nemzetiségúek egymáshoz viszonyítva Erdélyben 1930-ban

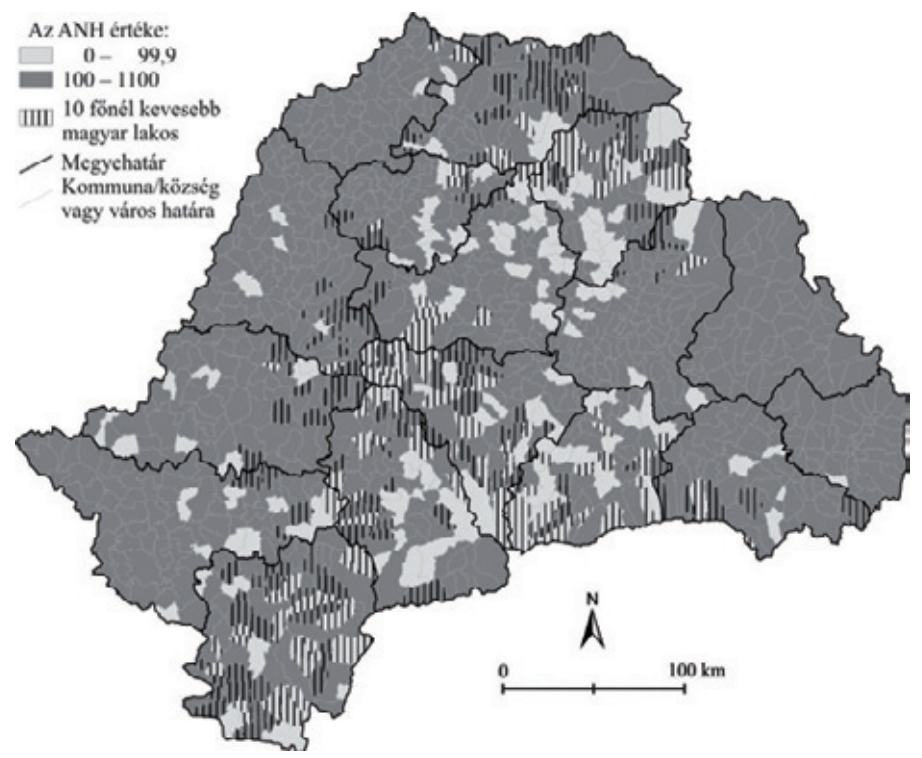

Forrás: Az 1930. évi román népszámlálás adatai. 
már-bihari magyar tömb, illetve a Székelyföld egyes részei emelkednek ki: az Erdővidék, Kézdiszék, Marosszék és Gyergyó. Ezekben a térségekben elsősorban magyar anyanyelvü románok éltek 1930-ban. Román anyanyelvü magyarokat fóként a Radnai-havasok - Mezőség - Kudzsiri-havasok közti sávban találunk, azaz a román tömb területén. A magyar-német kapcsolatok már 1930-ban is Szatmárban voltak a legintenzívebbek, itt, illetve a mai Arad megyében (Világos környékén) jellemző a magyar anyanyelv és a német nemzetiség tömegesebb kombinációja. Fordított esetre kevesebb példa van, elsősorban Krassó-Szörény megye hegyvidéki területein. A magyar anyanyelvü zsidóság több tízezres tömege elsősorban a Partium területén (főleg a Maros és a Szamos között), valamint kisebb mértékben a Székelyföldön helyezkedett el. Természetesen legnagyobb közösségeik a nagyobb városokban, ipari központokban laktak. Jiddis anyanyelvü magyarok gyakorlatilag nem éltek Erdélyben. Magyar anyanyelvü cigányok nagyobb számban ott fordultak elő, ahol magyar nyelvü románok is (tehát magyar többségü területeken), ezen túlmenően nagyobb számban éltek még Nagyszalontától délre, valamint Tordától délre, az Aranyosszék területén.

A 2. világháború éveinek eseményei erőteljesen meghatározták az interetnikus kapcsolatokat és a területi-települési jellemzőket. 1956-ra a zsidóság részesedése a magyar jellegü etnikumközi kapcsolatokban (a zsidók deportálása, lélekszámának drasztikus csökkenése miatt) 20\%-ra csökkent. Ezzel párhuzamosan a magyar-román kapcsolatok intenzitása nőtt (58\%-ra), aminek hátterében inkább azt sejthetjük, hogy az 1956. évi népszámlálás alkalmával - a felvétel pozitív szemléletváltozásának köszönhetően - többen vállalták kettős identitásukat, a magyarsághoz való kötődésüket. Varga E. Árpád (2002, 203.) szerint „a konszolidált népszámlálással az első főhatalomváltás óta tartó, elhúzódó »reasszimilációs korszak« is véget ért", ami annyit tesz, hogy 1956-ig a magyarság (statisztikailag) csak a korábban hozzá asszimilálódókat vesztette el. Tömeges különválásról azonban 1966-ig nem beszélhetünk.

Az 1966-os ANH, illetve a homogenizációs index értékeit nagyban befolyásolja az a tény, hogy a magyarokon és németeken kívül szinte az összes kisebbség rendkívül alacsony számban vállalta származását, így elsősorban a magyar nyelvű cigányok és zsidók száma esett vissza az - utóbbiak számát folyamatos kivándorlásuk is apasztotta. Ennek köszönhetően a magyar anyanyelvi és nemzetiségi értékek igen közel kerültek egymáshoz (2. táblázat). A csökkenő számú etnikumközi kapcsolatot a románok dominálták (64\%), a többi fontosabb nemzetiség (zsidó, német, cigány) $10 \%$ körül részesedett.

Fontos kérdés azonban nemcsak e kapcsolatok nagysága, hanem iránya is. 1966-ig lényegében minden etnikummal szemben anyanyelvi többlete volt a magyarságnak (3. táblázat). Ugyanakkor teljesen más struktúrája volt a magyar anyanyelvü, de egyéb nemzetiségü csoportnak, mint a magyar nemzetiségü, de egyéb anyanyelvűnek. Az előbbi csoportban 1966-ig a kapcsolatok többségét a románok adták, de - a zsidóság lélekszámának csökkenésével - egyre nagyobb részesedést ért el a német és főleg a cigány nemzetiségű lakosság. A második csoport viszont gyakorlatilag a magyar-román viszonylatot jelentette. 
3. táblázat: A romániai magyar népesség interetnikus kapcsolatrendszere nemzetiségenként, 1956-2002

\begin{tabular}{|c|c|c|c|c|c|}
\hline \multirow[t]{3}{*}{$\bar{E} V$} & \multirow{3}{*}{$\begin{array}{l}\text { Magyar anyanyelvü, } \\
\text { más nemzetiségü, fö }\end{array}$} & \multicolumn{4}{|c|}{ Ebböl } \\
\hline & & román & cigány & német & zsidó \\
\hline & & \multicolumn{4}{|c|}{ nemzetiségü, \% } \\
\hline 1956 & 88741 & 51,8 & 9,7 & 6,9 & 25,8 \\
\hline 1966 & 49614 & 56,7 & 13,2 & 8,0 & 15,7 \\
\hline 1992 & 48845 & 31,5 & 38,6 & 23,8 & 2,6 \\
\hline 2002 & 46064 & 30,1 & 52,0 & 13,9 & 1,4 \\
\hline \multirow[t]{3}{*}{$\bar{E} V$} & Magyar nemzetiségü, & \multicolumn{4}{|c|}{ Ebböl } \\
\hline & más anyanyelvü, fö & román & cigány & német & jiddis \\
\hline & & \multicolumn{4}{|c|}{ anyanyelvü, \% } \\
\hline 1956 & 22716 & 83,4 & 3,9 & 11,7 & 0,0 \\
\hline 1966 & 17333 & 84,6 & 3,8 & 10,0 & 0,0 \\
\hline 1992 & 34669 & 95,0 & 1,9 & 2,3 & 0,0 \\
\hline 2002 & 33901 & 94,6 & 3,1 & 1,5 & 0,0 \\
\hline
\end{tabular}

Forrás: Varga 1998b, 255.

1966-ban az ANH települési értékei sokkal kisebb szórást mutattak, mint 1930ban. A legkisebb értékeket a korábbiakhoz hasonlóan ekkor is ott találjuk, ahol a legkevesebb magyar lakos élt, azaz Fehér, Hunyad, Krassó-Szörény és Beszterce-Naszód hegyvidéki területein. Ugyanakkor a magasabb értékkel rendelkező települések koncentrációja és darabszáma is csökkent; leginkább a Partium északi részének határvidékein kereshetjük őket (2. ábra).

2. ábra: Magyar anyanyelvúek és nemzetiségúek egymáshoz viszonyítva Erdélyben 1966-ban

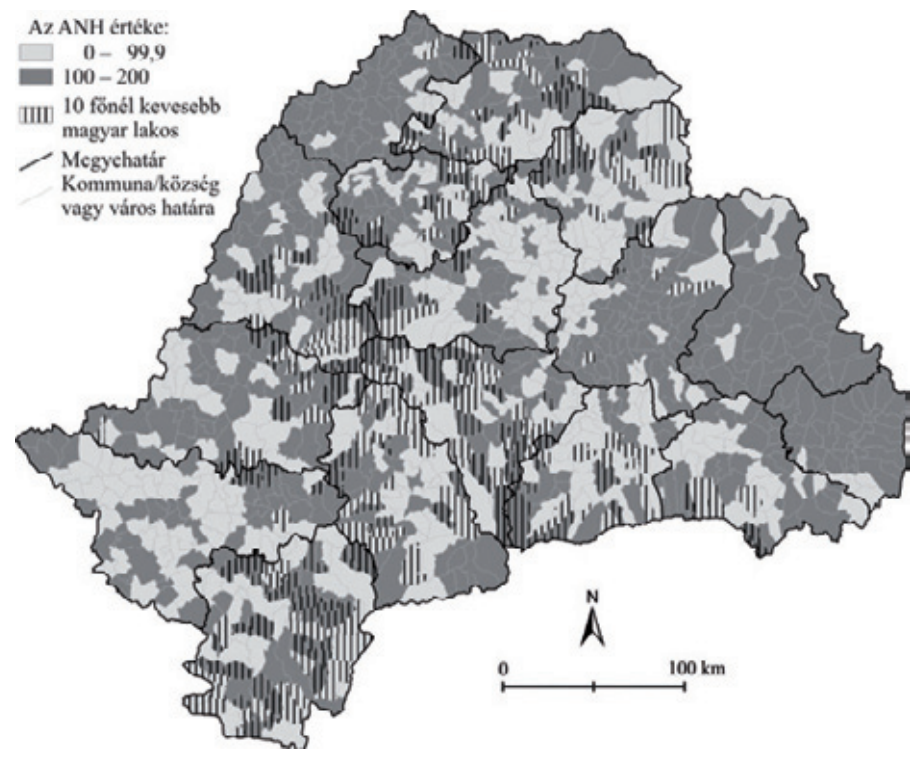

Forrás: Az 1966. évi román népszámlálás adatai. 


\section{6-2002}

Az 1966-1992 közötti időszak a korábbiakhoz képest jelentős átrendeződést hozott. Számottevően megnőtt a magyar nemzetiségủek aránya a hibrid népességen belül, ami szinte kizárólag a román anyanyelvű magyar népesség hatalmas növekményéből származik (lélekszámuk több mint kétszeresére nőtt). Ezzel szemben a magyar anyanyelvü románok száma megfeleződött; e két jelenség együtt a magyarok számára rendkívül kedvezőtlen demográfiai folyamatokat sejtet. A német lakossággal fennálló interetnikus kapcsolatok teljesen megváltoztak: egyrészt a nyelvét jobban megőrző szász és bánsági sváb lakosság nagy többsége kivándorolt (főleg az utóbbiak között fordult elő korábban a német anyanyelv - magyar nemzetiség kombináció), így e kategórián belül (magyar nemzetiségü, más anyanyelvü) a németek aránya 10\%-ról 2,3\%-ra csökkent. Ezzel párhuzamosan a leggyengébb etnikai öntudatú csoportjuk - a teljes mértékben asszimiláltnak hitt - szatmári svábok új öntudatra ébredtek, és tömegesen vallották a német nemzetiséget magyar anyanyelvük mellett. ${ }^{10}$ Mindez azt eredményezte, hogy a vonatkozó kategóriában a németek aránya nyolcról 23,8\%-ra emelkedett. A németek disszimilációja mellett a cigányság hasonló öntudatra ébredése is megfigyelhető; részesedése a népszámlálási magyar bevallásokban már csak azért is emelkedik folyamatosan (ebben az időszakban 13,2-ről 38,6\%-ra), mert magyar anyanyelvü csoportjainak még így is csak töredéke vallja magát cigány nemzetiségünek. Az utolsó fontosabb befolyásoló tényező pedig a magyar nyelvű zsidóság számának végleges lecsökkenése volt.

Ha az ANH adatait térképre vetítjük, 1992-re teljesen új, kikristályosodó állapotot láthatunk. Eszerint az ANH értékei már szinte csak a magyar tömbök területén érik el a 100-at: a Székelyföldön, illetve a partiumi (Szatmár-Bihar-Szilágy) tömbön kívül még Nagyszalonta környékén és pár kalotaszegi településen. Érdekesség, hogy a Fekete-Körös völgyének és a környező dombságoknak magyarok által kevésbé lakott részein is kiemelkedő értékekkel találkozunk - csakúgy, mint 1930-ban. Ennek okait valószínűleg helyi sajátosságokban kell keresnünk. 1992-ben a másik kiugró ANH-értékekkel rendelkező régió Szatmár volt, ahol az immár többszáz éves együttélés és keveredés hatására ismét rengetegen deklarálták magukat magyar anyanyelvü németnek, románnak, illetve cigánynak (vö. Tátrai 2010, 74-77.). A másik végpontot a magyarok által ekkor már alig lakott régiók jelentik, amelyek főleg Dél-Erdélyben, illetve a beszterce-naszódi és máramarosi hegyvidékeken keresendők (3. ábra).

1992 és 2002 között csak két lényeges változás történt. A szatmári svábok többsége visszatért a magyar nemzetiséghez („reasszimiláció”), így a német lakossághoz füződő interetnikus kapcsolatok nagysága a rendszerváltást megelőző szintre esett vissza. Ezt ellensúlyozta a roma lakosság fokozódó disszimilációja, azaz egyre többen vállalták cigány nemzetiségüket (ma- 
3. ábra: Magyar anyanyelvǔek és nemzetiségűek egymáshoz viszonyítva Erdélyben 1992-ben

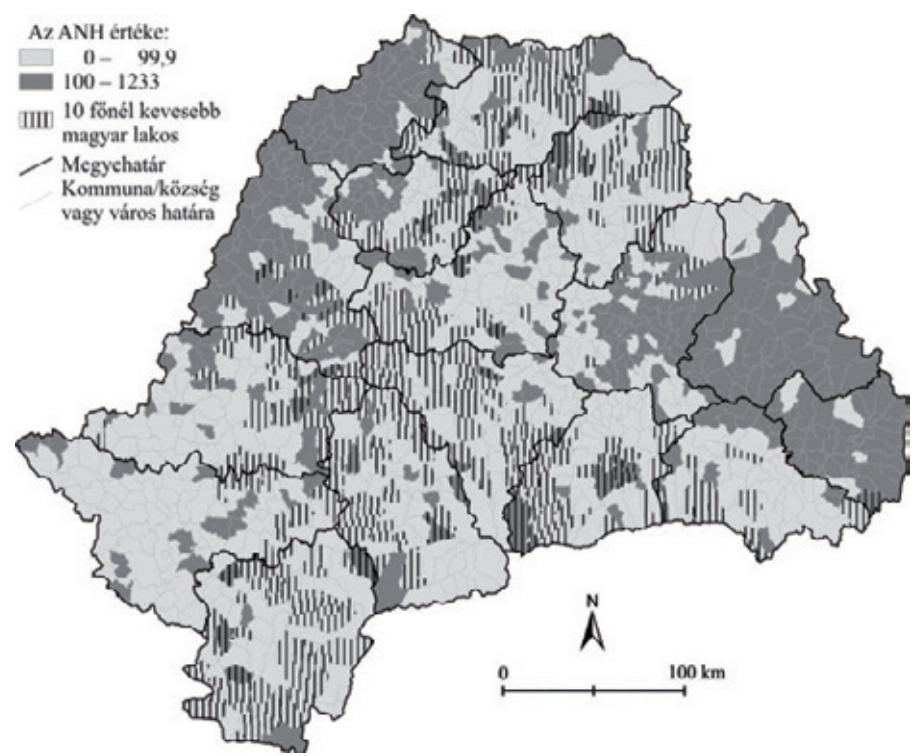

Forrás: Az 1992. évi román népszámlálás adatai.

gyar anyanyelvük mellett). Magyar-román viszonylatban számottevő változás nem történt.

A tíz évvel korábbi állapothoz képest tovább csökkent a 100 feletti ANHértékkel rendelkező közigazgatási alapegységek (községek, városok) száma. 2002-re három jól lehatárolható tömb alakult így ki: a Székelyföld, a szatmár-bihari határ menti sáv, valamint a Szilágyság magyarlakta részei. Rendkívül feltűnő még az egybeesés a 20\% felett magyarok lakta vidékekkel Nagyszalontától délre. Ugyanakkor a Fekete-Körös völgyének korábbi magyar anyanyelvi többlete szinte egységesen nemzetiségi többletté változott. A gyakran harmadik tömbként is emlegetett Kalotaszegen már csak annak magyar többségü magjában van anyanyelvi többlet (4-5. ábra).

Az interetnikus kapcsolatok térbeli megoszlása is sokat változott az elmúlt hetven évben. A 10 fő feletti magyar lakossággal rendelkező közigazgatási alapegységeket vizsgálva megállapítható, hogy magyar-román viszonylatban dominánssá vált a román anyanyelv és magyar nemzetiség kombinációja. Eme jelenség koncentráltabb elöretörése figyelhető meg a magyar többségü területeken kívül szinte mindenütt, de különösen feltűnő a Bánságban, Nagybánya tágabb környékén, a Mezőségen, a Nagy-Küküllő völgyében, a Barcaságban, Hunyad megye déli részén, illetve - más megközelítésben - a 122 városból 102-ben. Magyar anyanyelvű román lakosság nagyobb számban már csak Nagyvárad és Halmi között, illetve Kovászna megyében él. A magyar-német 
4. ábra: Magyar anyanyelvǔek és nemzetiségűek egymáshoz viszonyítva Erdélyben 2002-ben

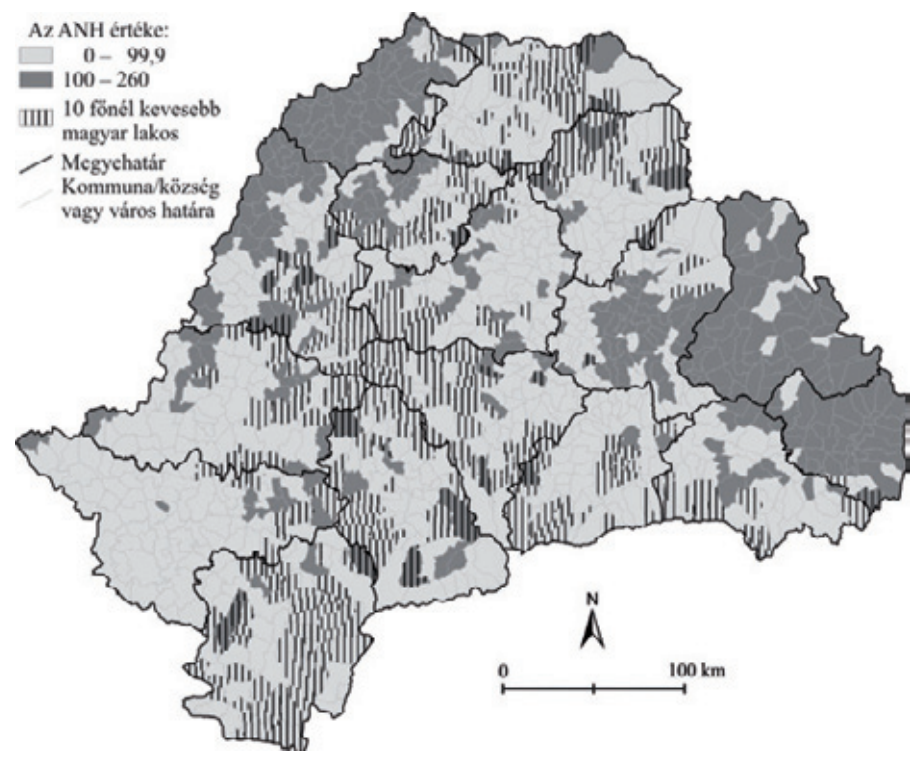

Forrás: A 2002. évi román népszámlálás adatai.

5. ábra: A magyar anyanyelvű lakosság Erdély alapszintú közigazgatási egységeiben, 2002-ben

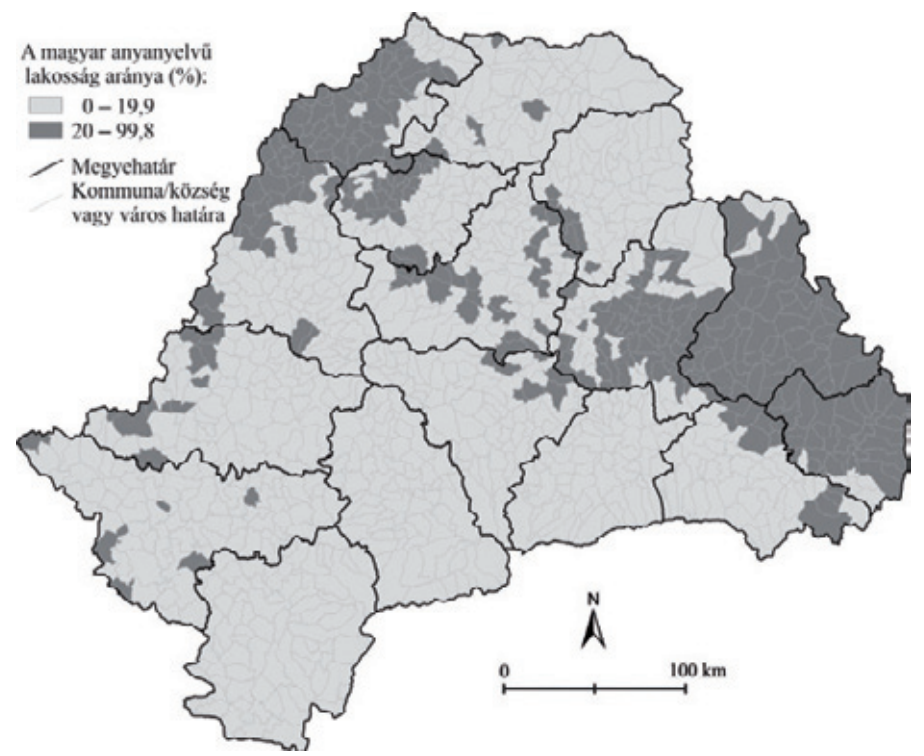

Forrás: A 2002. évi román népszámlálás adatai. 
kapcsolatok gyakorlatilag egyetlen színhelye napjainkban Szatmár megye, ahol magyar anyanyelvű német közösségek élnek a határ menti Szaniszlótól az Avasság peremén elhelyezkedő Józsefházáig. A németekhez hasonlóan aszimmetrikus, magyar anyanyelvi többségü a cigány-magyar hibrid lakosság is. Elterjedése szinte pontosan megfeleltethető a 20\% feletti magyar lakosságú térségeknek, amelyek közül mindössze Udvarhelyszéken nem él számottevő magyar anyanyelvű cigány közösség a 2002-es népszámlálás szerint.

Megyei szinten áttekintve a képet megállapítható, hogy lényeges különbséget találunk több szempont szerint is. A legfontosabbnak az Észak- és DélErdély közti különbség tűnik (vö. Szilágyi 2004). Ez leginkább a magyarság hagyományos településterületéből eredeztethető, amely elsősorban Észak-Erdélyre koncentrálódik. Részben ebből vezethető le a jelen különbségek egy másik okozója, az 1940-44 közötti magyar uralom Észak-Erdélyben, mely egyes - a magyarság számára - kedvezőtlen folyamatokat (időlegesen) megállított. A megváltozott hatalmi viszonyok szerepét elsősorban Beszterce-Naszód megye magyarságának mutatóira alapozom, hiszen a vizsgált periódus elején itt volt a legkedvezőtlenebb az ANH, ugyanakkor nem következett be oly mérvű szórványosodás, mint egyes dél-erdélyi megyékben (4. táblázat). A harmadik fontos különbség a falvak és a városok között figyelhető meg.

Az 4. táblázat alapján érdemes megfigyelni néhány sajátosságot. A kezdeti, egyértelmű anyanyelvi többlettel jellemezhető állapotot 1966-ig felváltotta

4. táblázat: A magyar ANH és homogenitási index változása az erdélyi megyékben, 1930-2002

\begin{tabular}{|c|c|c|c|c|c|c|c|c|}
\hline \multirow[t]{2}{*}{ Megye } & \multicolumn{6}{|c|}{ ANH } & \multicolumn{2}{|c|}{$\begin{array}{c}\text { Homogenitás } \\
\text { index }\end{array}$} \\
\hline & 1930 & 1966 & 1992 & 2002 & $\begin{array}{c}2002, \\
\text { váro- } \\
\text { sok }\end{array}$ & $\begin{array}{l}2002, \\
\text { falvak }\end{array}$ & 1992 & 2002 \\
\hline Arad & 116,5 & 103,8 & 99,2 & 98,0 & 97,7 & 98,3 & 93,1 & 91,6 \\
\hline Beszterce-Naszód & 98,1 & 96,5 & 93,2 & 93,4 & 93,1 & 93,6 & 91,7 & 91,5 \\
\hline Bihar & 112,7 & 102,7 & 102,2 & 103,7 & 102,2 & 105,7 & 95,8 & 94,2 \\
\hline Brassó & 104,8 & 101,9 & 99,3 & 99,5 & 98,7 & 101,3 & 93,5 & 93,4 \\
\hline Fehér & 102,1 & 99,0 & 94,8 & 95,3 & 93,1 & 97,8 & 91,9 & 92,5 \\
\hline Hargita & 103,0 & 100,7 & 100,8 & 100,9 & 101,0 & 100,8 & 98,8 & 98,7 \\
\hline Hunyad & 107,5 & 100,5 & 92,9 & 89,3 & 89,7 & 80,6 & 86,9 & 83,7 \\
\hline Kolozs & 107,2 & 100,8 & 98,9 & 98,6 & 98,5 & 98,8 & 96,6 & 96,4 \\
\hline Kovászna & 107,8 & 101,3 & 101,2 & 101,5 & 101,7 & 101,2 & 98,2 & 97,9 \\
\hline Krassó-Szörény & 103,3 & 95,8 & 89,8 & 84,1 & 84,9 & 79,1 & 82,9 & 76,8 \\
\hline Máramaros & 115,6 & 103,8 & 98,9 & 97,0 & 96,7 & 98,1 & 92,5 & 92,2 \\
\hline Maros & 106,7 & 101,3 & 101,2 & 101,4 & 101,6 & 101,1 & 97,3 & 96,7 \\
\hline Szatmár & 133,5 & 105,1 & 111,6 & 111,0 & 105,4 & 116,2 & 88,2 & 88,7 \\
\hline Szeben & 103,8 & 98,8 & 93,5 & 91,3 & 92,3 & 86,6 & 90,0 & 88,5 \\
\hline Szilágy & 103,6 & 100,2 & 100,1 & 100,1 & 100,6 & 99,9 & 98,3 & 98,0 \\
\hline Temes & 108,5 & 103,4 & 97,2 & 94,4 & 94,4 & 94,2 & 90,0 & 88,0 \\
\hline Erdély & 109,4 & 101,8 & 101,0 & 101,0 & 99,9 & 102,2 & 95,3 & 94,9 \\
\hline
\end{tabular}


6. ábra: Erdély magyar lakosságának homogenitási indexe, valamint interetnikus kapcsolatainak iránya 2002-ben

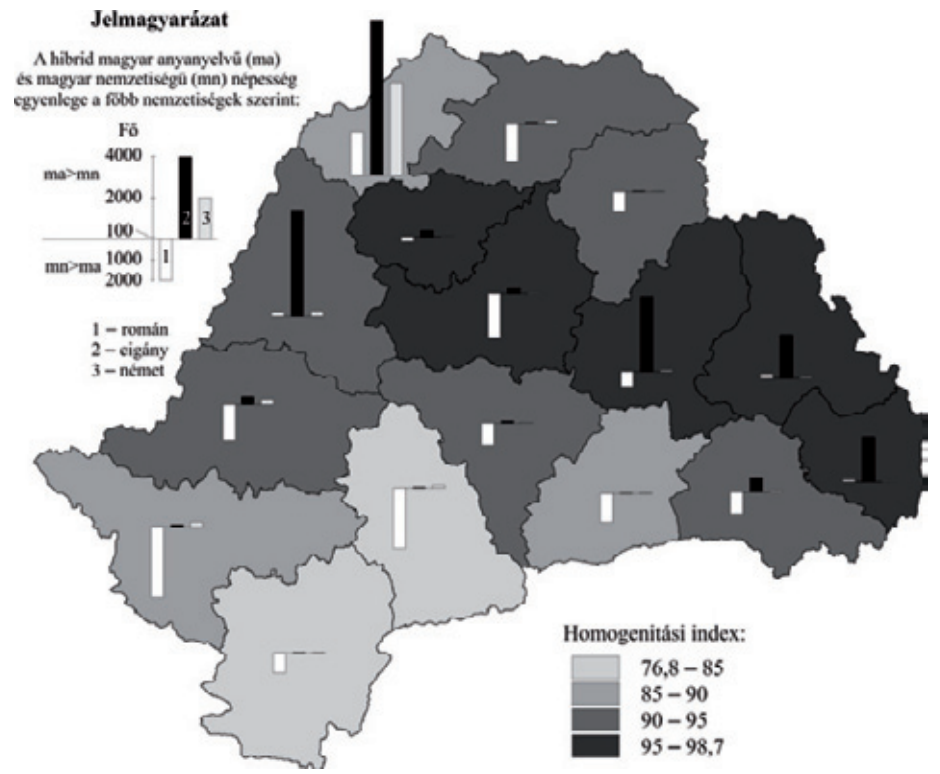

Forrás: A 2002. évi román népszámlálás adatai.

egy egyensúlyközeli állapot; mindössze azon megyék esetében kisebb az ANH értéke száznál, ahol már korábban megindultak a magyarság számára kedvezőtlen folyamatok. 1992-re az ANH alapján egyértelműen kettévált a vizsgált terület a "tömb" (Bihar, Szatmár, Szilágy, Hargita, Kovászna, Maros) és a „szórvány" megyéire. 2002-ig az utóbbi csoportban - Fehér megyét leszámítva - tovább csökkent az ANH és a homogenitás értéke; leginkább Krassó-Szörény és Hunyad megyékben válik el egymástól a magyar anyanyelvűek és a magyar nemzetiségüek csoportja. A tömb megyéi közül kiemelném Szilágy megyét, ahol az interetnikus kapcsolatok már a kezdetektől rendkívül szűkek; ezzel szemben a szomszédos Szatmárban páratlanul gazdagok: románokkal, cigányokkal, németekkel egyaránt (6. ábra). A homogenitás mértéke és az interetnikus kapcsolatok iránya is jelentősen különbözik Dél- és Észak-Erdélyben: az előbbiben a kapcsolatok zöme a románokhoz füződik, ezen belül pedig a magyar nemzetiségű hibridek többlete figyelhető meg, míg az utóbbiban a magyar-román kapcsolatok kiegyensúlyozottabbak, és a magyar anyanyelvü cigány lakosság a meghatározó a magát csak az egyik kategória szerint magyarnak vallók között.

A fentiek egyik magyarázatát a falu-város-különbségekből is levezethetjük. Általánosságban elmondható, hogy azokban a megyékben, ahol a falusi magyar lakosság „öshonosnak” tekinthető, ${ }^{11}$ ott a falvak ANH-értéke 
közelebb esik 100-hoz, mint a városoké. Bihar és Szatmár megyékben elsősorban a rurális térségekben élő magyar nyelvü cigányok okozzák a magas falusi ANH-értékeket. Ezzel szemben Dél-Erdélyben - mivel az ottani megyék urbanizáltsági foka magasabb, és a magyar lakosságnak is nagyobb hányada él városban - a városi magyarok körében magasabb e mutató. Összességében az erdélyi adatok alapján azt mondhatjuk, hogy a városokban levő magyar nemzetiségi többlet a városi közeg erősebb asszimiláló hatásáról tanúskodik - természetesen főleg azokban a városokban, ahol a magyarok kisebbségben élnek.

\section{Következtetések}

A fent ismertetett folyamatokat több összetevő befolyásolja, a bevezetésben említett kérdésekre tehát több szempontból is keresem a választ.

Anyanyelv és nemzetiség egymáshoz való viszonyát tekintve több triviálisnak tünő sajátosságra is felfigyelhetünk, amelyek azonban alapvetőek az okokozati összefüggések megértéséhez. Így tehát anyanyelv és nemzetiség egymáshoz viszonyítva térben és időben rendkívül változékony, függvénye a mindenkori hatalomnak, a demográfiai és a politikai többségnek, azaz másmilyen kisebbségben és másmilyen többségben. Ezen túlmenően anyanyelv és nemzetiség kapcsolatának térbeli (tömb-szórvány), számbeli (az egyes etnikumokhoz tartozók száma) és hatalmi (etnikai hierarchia) összetevői is vannak.

E két népszámlálási kategória egymástól való eltérése mindenképpen az asszimiláció eredménye. Az asszimiláció irányát, de elsősorban a nagyságát az egyes etnikumok lélekszáma, térbeli koncentrációja határozza meg. A hatalmi viszonyok pedig fóként a hasonulás irányát befolyásolják. Az etnikai hierarchiát elsősorban az határozza meg, hogy ki tartozik a többségi/államalkotó nemzethez, illetve ki van kisebbségben. Ugyanez lokálisan is müködhet: sokszor - az amúgy kisebbséghez tartozó - helyi többség dominálja az interetnikus viszonyokat. Ugyanakkor a múltbeli hatalmi viszonyok helyenként napjainkig hatnak, ez elsősorban a magyar lakosság magasabb presztízsében nyilvánulhat meg. Jelenleg Erdélyben az etnikai hierarchia csúcsán vagy román vagy magyar lakosság található. A cigányság - még ha többségben is van - a legkevésbé elfogadott, legkisebb presztízsű népcsoport (Bakó 2002, Túrós 1996). Ez a rangsor tehát meghatározza az esetleges asszimiláció irányát, amely országosan mindig a többségi nemzet irányába mutat, azonban lokálisan/regionálisan akár fordított is lehet a folyamat. A városok részletesebb adatai alapján elmondható, hogy a kisebb lélekszámú népcsoportok (például németek, ukránok és városban a cigányok is) gyakorlatilag mindig a helyi többséghez hasonulnak. 
A helyi többséghez hasonulás önmagában azonban nem válaszolja meg azt, hogy miért pont ott és úgy térnek el az anyanyelvi és a nemzetiségi bevallások. A magyar lakosság esetében az ANH értéke nem csak ott érte el a 100at, ahol a magyarok éltek többségben (ld. a 4. és 5. ábrán). Azaz a számbeli összetevők nem magyaráznak meg mindent, véleményem szerint a választ a térbeli vizsgálatok adják meg.

A 4. és 5. ábra alapján jól látszik, hogy összefüggő magyar anyanyelvi többlet csak a Székelyföldet és a Partium északnyugati részét, tehát a magyar tömböt jellemzi. Azonban a magyar tömbön belül, illetve annak peremén számos olyan település található, ahol a magyarok aránya $20 \%$ körül mozog, és anyanyelvi többlet jellemzi, míg például a Mezőségben sok helyen a helyi magyar többség ellenére nemzetiségi többlet van. Alapvetően tehát a különbséget nem a magyarok számára és arányára, hanem térbeli elhelyezkedésére kell visszavezetni (azaz hogy tömb, avagy szórvány lakói-e).

A fenti gondolatmenet alapján az következik tehát, hogy a magyar anyanyelvi és a magyar nemzetiségi többlettel rendelkező területek közötti különbséget a tömb és a szórvány identitása közötti különbségben kell keresnünk. Ilyés Zoltán $(2005,145$.) szórványdefiníciója illeszkedik is e feltételezéshez: „A szórványok pontos kvantitatív behatárolásai, asszimilációelméleti meghatározásai és társadalomtudományos körülírásai ellenére a Kárpát-medencei összmagyar diskurzusban, a tudományos, politikai és laikus nyilvánosságban valamiféle hallgatólagos közmegegyezés szerint minden szórvány, ami nem a tömbmagyarsághoz tartozik, amelyet bizonyos diszperzió, térbeli keveredettség - érzelmesebben megfogalmazva - magárahagyatottság jellemez." A mintegy 90 éve kisebbségi sorban élő magyarok esetében természetesnek tűnik, hogy eltérő módon fejlődik az etnikai identitása azon csoportjaiknak, akik behatárolt nyelvhasználati lehetőségekkel, szűk anyanyelvi intézményi háttérrel rendelkeznek (pl. oktatás), tehát kialakulhat egyfajta szórványidentitás (Bodó 2009, 102-103.). Összességében a népszámláláson bevallott anyanyelv és nemzetiség különbségének térképre vetítése egyúttal egy szórványlehatárolási lehetőség is.

Azonban önmagában az anyanyelv-nemzetiség-különbségből, e két adatsorból nem lehet teljes egészében megérteni, levezetni az asszimilációs folyamatokat, illetve azt, hogy kik alkotják a hibrid népességet. Így például nem állítható, hogy a magyar anyanyelvü, de más nemzetiségüek teljes egészében etnikai asszimilánsok, illetve a magyar nemzetiségü, más anyanyelvűek pedig nyelvileg hasonultak volna. ${ }^{12} \mathrm{~A}$ hibrid népesség létrejöttében egyrészt (akár egyidejű) asszimilációs és disszimilációs folyamatok ${ }^{13}$ játszanak közre, amelyek ráadásul nemzetiségenként eltérő irányúak és nagyságúak. Így például a statisztikai adatok alapján a Székelyföld egyes multietnikus városaiban egyszerre figyelhető meg a magyarok irányába mutató asszimiláció (németek, cigányok) és a magyarok beolvadása a románokba.

Milyen törvényszerüségeket lehet tehát látni? A korábban vázolt folyamatok alapján a magyar nemzetiségü, román anyanyelvü csoport tűnik a legin- 
kább egyértelműnek: e csoport nagy többségét az elmúlt években/évtizedekben nyelvi asszimiláción átesett magyar származású népesség adja. Elterjedési területe leginkább a - magyar szemszögből - szórványvidékekre jellemző, e tekintetben elsősorban a dél-erdélyi megyék emelkednek ki. A magyar anyanyelvü, román nemzetiségü csoport meghatározása már kicsit bonyolultabb. Eredete szerint két csoportra tagolhatjuk: egyrészt a magyar uralom alatt nyelvileg elmagyarosodott ortodox/görög katolikus vallású lakosságra, másrészt a magyar tömbök területén az utóbbi időszakban elmagyarosodó lakosságra. Az utóbbinál most zajlik a magyarok irányába mutató egyfajta hasonulás, az előbbinél pedig - amely az adatok alapján a nagyobb csoport - egy folyamatban levő vagy akár lezajlott asszimilációt követett egy (román uralom alatti) disszimiláció. Bár Szilágyi $(2004,166$.) szerint a nyelvi és az etnikai identitás „disszonanciája a mi kultúránkban nem egy hosszú ideig fenntartható állapot”, ennek ellenére szatmári kutatásaim alapján egész közösségeket jellemez ez a fajta kettős identitás immár évtizedek óta. Szatmárban főként Petén, Domahidán, Vetésen, Szatmárudvarin és Batizon jellemző, hogy 1930 óta az összes népszámláláson sokan vallják magukat magyar anyanyelvűnek és román nemzetiségűnek. Az első két faluban a heteroidentifikáció alapja a vallás, származás, így bár a két helységben gyakorlatilag a lakosság egésze magyar anyanyelvü, az ortodoxok/görög katolikusok mégis románnak számítanak, a reformátusok pedig magyarnak (illetve cigánynak). ${ }^{14} \mathrm{Ettől}$ azonban jelentősen eltér az autoidentifikáció, hiszen a népszámlálásokból kitűnik, hogy a reformátusok számánál jóval magasabb a magyar nemzetiségűek száma ott is, ahol nincs cigány népesség. A nyelvi és etnikai identitás bizonytalansága ugyanakkor stabil vallási identitással párosult, aminek következtében az utóbbi sokszor meghatározóbb, mint az etnikai azonosságtudat (Tátrai 2010, 105-152.). ${ }^{15}$

Magyar-német-viszonylatban napjainkra már csak a magyar anyanyelvü német nemzetiségüek (többségükben szatmári svábok) képeznek számottevő csoportot. Esetükben egyértelmü, hogy többségük a 20. század első felére mind nyelvileg, mind etnikailag asszimilálódott, ennek ellenére a század végére disszimilációt tapasztalhattunk körükben. Ezt a fellángolást azonban reasszimiláció követte. A szatmári németekről sokat elárul, hogy jelentős részük nem beszél már németül, ${ }^{16}$ illetve a parlamenti választások alkalmával a sváb falvakban az RMDSZ-re leadott voksok aránya messze meghaladja a magyar nemzetiségüek arányát. Ráadásul felméréseim szerint a sváb falvak német és magyar lakossága gyakorlatilag elkülöníthetetlen egymástól. Másképpen fogalmazva: ezekben a falvakban a katolikus lakosság magyar anyanyelvü, és többes etnikai identitással rendelkezik (Tátrai 2010, 106-134.).

A magyar-német-kapcsolatokhoz hasonlóan magyar-cigány-viszonylatban is a magyar anyanyelvü, cigány nemzetiségü népesség a domináns. A cigányság nagy része nyelvileg - csakúgy, mint vallásilag - a környezetéhez idomult, cigány anyanyelvét csak ott tartotta meg, ahol több nemzetiség keveredve 
élt. ${ }^{17}$ Így bizton állíthatjuk: jelentősebb számú hibrid cigány-magyar népesség csak ott él, ahol az elmúlt két évszázadban magyarok nagyobb számban éltek.

\section{Összegzés}

Térségünk legtöbb országában - Magyarország kivételével - az etnikai kötődésre utaló kérdéseknél nincs meg a lehetőség több identitás választására nemzetiség szerint, vagy akár több anyanyelv bevallására, éppen ezért a bizonytalan/többes identitás egyik megnyilvánulása, ha valaki eltérő anyanyelvet és nemzetiséget vall be.

Az eltérés legfőbb okozója a nyelvi asszimiláció, hiszen általában csak utána következik be az etnikai asszimiláció, ami általában már a „hibrid” kategóriából való kikerülést eredményezi. Az asszimiláció katalizátorai a vegyes házasságok, illetve a többségi nyelven történő szocializáció (pl. iskola).

$\mathrm{Az}$ anyanyelv-nemzetiség-eltérés nagysága és iránya térben és időben változó, leginkább az adott etnikum számával és területi elhelyezkedésével hozható összefüggésbe, de a hatalmi viszonyok is jelentős szerepet játszanak benne. Ennek köszönhetően lényeges eltérések vannak a magyar lakosság interetnikus viszonyaiban nemzetiségek szerint. Erdély magyar népességét tekintve a térbeli elhelyezkedés tűnik a legfontosabb tényezőnek: a magyar nemzetiségi többletű területeket általában a szórványidentitás jellemzi, míg a magyar anyanyelvi többletű részeken a kiegyensúlyozott etnikai identitás dominál.

A fent elmondottak nemcsak az erdélyi magyarságra igazak, a népszámlálási adatok alapján Ukrajna, Szerbia és Horvátország magyarságára is ez jellemző, míg Szlovákia és Szlovénia magyar lakossága eltérő sajátosságokkal bír anyanyelv és nemzetiség viszonyát illetően. Arra a kérdésre, hogy milyen okai vannak az országcsoportok közötti eltérésnek, e tanulmány keretében nem tudtam kitérni, a válaszhoz további kutatások szükségesek.

\section{Köszönetnyilvánítás}

A tanulmány az OTKA K 77973 számú kutatásának keretében készült.

\section{Jegyzetek}

1 Részletesen ld. Skutnabb-Kangas $(1997,13$.$) .$

2 Államnemzet- vagy politikainemzet-felfogás: az összetartozás alapja a közös terület, a közös államhoz való tartozás (Romsics 2004, 9.). 
Jelen dolgozatban Erdélyen a Magyarországtól 1920-ban Romániához csatolt területet értem.

4 Az okokra leginkább csak közvetve következtethetünk az egyes szférákba sorolt csoportokból. Belső szféra: vegyes házasságból származók, ahol anyanyelvük utal származásukra, nemzetiségük pedig az „új” identitásukat tükrözi. Idetartozhatnak még homogén közegből származó, de nem anyanyelvi oktatásban részesülők is. Külső szféra: egy részük vegyes származású, de lehetnek köztük a többségi környezetben szocializálódott homogén származásúak, akik származás szerinti nemzeti hovatartozásukat megtartották (Gyurgyík 2006b., 81.). Sajnos ezek alapján nem sorolható be a szlovákiai roma népesség, illetve azok, akik csak „statisztikailag” váltottak nemzetiséget/anyanyelvet.

Bár elképzelhetőnek tartja azt is, hogy „a magyartól eltérő anyanyelvü magyarok jelenlétét olyan (a magyarok irányába történő) etnikai asszimilációval kell magyarázni, amely az eredeti anyanyelv megtartása mellett megy végbe, ez azonban elég valószínütlen, mert a sorrend inkább fordított szokott lenni” (Szilágyi 2004, 165.).

„A román nemzetiségű, ám magyar anyanyelvű személyek számának csökkenése és a magukat magyar nemzetiségűnek valló román anyanyelvűek számának növekedése értelmezésemben egyaránt a különválás jele. Előbbi jobbára az érintetteknek az államnemzethez történt visszatérését nyugtázza, míg az utóbbi ugyanoda irányuló átlépésüket előlegezi meg" (Varga 2002, 204.).

$7 \quad$ Azaz Szilágyi $(2004,168$.) gondolatmenete alapján például egy ortodox magyarból vagy utódaiból előbb-utóbb valószínűleg ortodox román lesz, de egy református román akár generációkon át megmaradhat vallásán és nemzetiségén. Itt kivételt csak azok a szatmári és székelyföldi román származású közösségek jelentenek, ahol a nyelvcsere már magyar uralom alatt lejátszódott.

A 2. világháború után az államnyelv elsajátításának fokozódó igénye és kényszere, a kisebbségi nyelvek háttérbe szorítása miatt ezen adatok torzulnak, ráadásul a megfelelő statisztikák hiányoznak is.

9 A mai közigazgatási beosztásra vetítem vissza az 1930-as és az 1966-os állapotot is.

10 A Varga E. Árpád (1998b, 255.) szóhasználatával „újsváb” öntudatuk kialakulásának hátterében minden bizonnyal a német útlevél megszerzésének, illetve a németországi kivándorlásnak a lehetősége állt (Schreiber 1993, 209.).

11 A Bánság és Hunyad 19. századi magyar telepeit nem tekintem őshonosnak.

12 Az asszimiláció fajtáit ld. Szilágyi (2004, 164-168.).

13 Fontos leszögezni, hogy jelen tanulmányban az asszimiláció gyűjtőfogalmába sorolom a vegyes házasságokból származó utódok esetét is (generációk közötti nyelv/nemzetváltás).

14 Hasonló jelenséget ír le a Brassó megyei Ürmösről Bakó Boglárka (2002).

15 „Az 1989 előtti utolsó népszámláláson Szatmárnémetiben megesett példa: A népszámlálást végző megkérdezi, milyen nyelven beszél a következő ház lakója. Megtudja, magyarul. Így köszön, kérdezi az adatokat. Nemzetisége? - Görög katolikus. - Nem a vallását kérdezzük, ilyen rovat nincs a kérdőívben. (A kérdezett nem érti, és kitartóan görög katolikusnak vallja magát.) - Magyar vagy román? - Román. - A kérdező: Miért nem mondta? Románul folytatja a kérdezést. - A kérdezett: Kérem, tessék magyarul mondani, mert én nem tudok románul. - Most mondta, hogy román. - Kérem, én batizi görög katolikus vagyok. - Nem a vallását kérdeztem, a nemzetiségét. - Tessék románt írni, nehogy baj legyen belőle" (Bura 2001, 117.).

Kutatásaim szerint Mezőteremben a németnek minősített lakosság mindössze 72\%-a, Krasznabélteken 78\%-a tudott még németül (Tátrai 2010, 109., 133.).

17 „Sőt épen az egynyelvü vidékeken, a hol tehát valamely nemzetiség feltétlenül uralkodik, találtatnak a legnagyobb arányban a czigányul nem tudó czigányok." (A Magyarországban..., 1895, 55.). 


\section{Irodalom}

Bakó B. (2002): Együttélési viszonyok és az etnikai identitás. In: Kovács N., Szarka L. (szerk.): Tér és terep. Tanulmányok az etnicitás és az identitás kérdéskörébool. Akadémiai Kiadó, Budapest, 87-109.

Bodó B. (2009): Szórvány és dinamika. In: Bodó B.: Szórvány és nyelvhatár. Lucidus Kiadó, Budapest, $100-106$.

Bura L. (2001): A keleti szertartású kereszténység múltja és jelene Szatmárban. Magyar görög katolikusok a Szamosháton (Szatmár megyében). Magyar Egyháztörténeti Vázlatok, 3-4., 103-120.

Gyurgyík L. (2006a): Népszámlálás 2001. A szlovákiai magyarság demográfiai, valamint település- és társadalomszerkezetének változásai az 1990-es években. Kalligram, Pozsony

Gyurgyík L. (2006b): Nemzetiség és anyanyelv szerinti hovatartozás a szlovákiai nemzeti, etnikai közösségek életében. In: Lelkes G., Tóth K. (szerk.): Národnostné a etnické menšiny na Slovensku 2005 - Nemzeti és etnikai kisebbségek Szlovákiában 2005. Fórum Kisebbségkutató Intézet, Somorja, 77-93.

Horváth I. (2008): Elemzések a romániai magyarok kétnyelvüségéról. Institutul pentru Studierea Problemelor Minoritatilor Naționale, Cluj-Napoca

Ilyés Z. (2005): Szórványkutatás, szórványértelmezés. Megjegyzések a Kárpát-medence szórványközösségeinek társadalomtudományi vizsgálatához. Magyar Tudomány, 2., 145-155.

Kocsis K. (2003): A Kárpát-medence változó etnikai arculata (1989-2002). Kisebbségkutatás, 4., 706-725.

A Magyarországban 1893. január 31-én végrehajtott czigányösszeírás eredményei. Magyar Statisztikai Közlemények, Új Folyam IX., 1895.

Mirnics K. (1998): Asszimilációs tényezők és asszimilációs politika Jugoszláviában (Vajdaságban). Regio, 2., 41-63.

Oláh S. (1996): Magyar görög katolikus „románok”. In: Gagyi J. (szerk): Egy más mellett élés: a magyar-román, magyar-cigány kapcsolatokról. KAM Regionális és Antropológiai Kutatások Központja, Pro-Print Könyvkiadó, Csíkszereda, 113-138.

Romsics I. (2004): Nemzet, nemzetiség és állam. Napvilág Kiadó, Budapest

Sebők L. (2006): A szlavóniai magyar szórványok. In: Bakó B., Szoták Sz. (szerk.): Magyarlakta kistérségek és kisebbségi identitások a Kárpát-medencében. Gondolat Kiadó, MTA Etnikai-nemzeti Kisebbségkutató Intézet, Budapest, 179-191.

Schreiber, W. E. (1993): Demographische Entwicklungen bei den Rumäniendeutschen. Südosteuropa Mitteilungen, 3., 204-211.

Skutnabb-Kangas, T. (1997): Nyelv, oktatás és kisebbségek. Teleki László Alapítvány, Budapest

Szilágyi N. S. (2004): Az asszimiláció és hatása a népesedési folyamatokra. In: Kiss T. (szerk.): Népesedési folyamatok az ezredfordulón Erdélyben. RMDSZ Ügyvezető Elnöksége, Kolozsvár, 157-234.

Tátrai P. (2010): Az etnikai térszerkezet változásai a történeti Szatmárban. MTA FKI, Budapest

Túros E. (1996): Magyarok, románok, cigányok: ki van a középpontban? In: Gagyi J. (szerk): Egy más mellett élés: a magyar-román, magyar-cigány kapcsolatokról. KAM Regionális és Antropológiai Kutatások Központja, Pro-Print Könyvkiadó, Csíkszereda, 165-180.

Varga E. Á. (1998a): Népszámlálások a jelenkori Erdély területén. In: Varga E. Á.: Fejezetek a jelenkori Erdély népesedéstörténetéból. Püski, Budapest, 10-63.

Varga E. Á. (1998b): Az erdélyi magyarság lélekszámáról. In: Varga E. Á.: Fejezetek a jelenkori Erdély népesedéstörténetéböl. Püski, Budapest, 240-259.

Varga E. Á. (2002): Az erdélyi magyarság asszimilációs mérlege a XX. század folyamán. Regio, 1., $171-205$.

Veres V. (2008): Analiza comparata a identitatii minoritatilor maghiaredin Bazinul Carpatic - A Kárpátmedencei magyarok nemzeti identitásának összehasonlitó elemzése. Institutul pentru Studierea Problemelor Minoritatilor Nationale, Cluj-Napoca 